\title{
Choosing the best diluent for a fixed catalytic bed: The case of $\mathrm{CO}$ hydrogenation
}

\author{
Claudia L. Bianchi *, Carlo Pirola, Vittorio Ragaini \\ Department of Physical Chemistry and Electrochemistry, University of Milan, Via Golgi 19, 20133 Milan, Italy
}

Received 23 September 2005; received in revised form 24 January 2006; accepted 7 February 2006

\begin{abstract}
Fixed bed reactors are frequently used for many catalytic reactions, but the difficult to remove the reaction heat in highly exothermic reactions can bring to a bad performance of the catalyst or to its fast deactivation. A possible solution is to use diluents, i.e., inactive ceramic bodies, tailored to mix intimately with the catalyst without affecting the fluid flow through the catalyst bed. The influence of the use of diluent materials on Fischer-Tropsch synthesis catalyst activity is here fully discussed.
\end{abstract}

(C) 2006 Elsevier B.V. All rights reserved.

Keywords: Fischer-Tropsch synthesis; Catalyst; cobalt; Iron; Fixed bed reactor; Reacti on heat; Diluent

\section{Introduction}

The fixed bed catalytic reactor is one of the most widely used reactor types in the refining and petrochemical industry. In its simplest form, it is a tube filled with a solid catalyst, through which gaseous (or, less frequently, liquid) reactants flow and they are converted into products.

One of the first questions that we must address in designing a fixed bed reactor is whether and how we will add or remove heat to and from the reactor. The simplest choice is to use an adiabatic reactor. Since heat transfer does not represent an issue in this case, the reactor can be a single vessel with a relatively large diameter, it will require no utilities during the steady-state operation, and only one single catalyst bed will be needed. Unfortunately, many important reactions cannot be successfully carried out in a single adiabatic reactor. If the reaction is adequately endothermic, then the temperature in the reactor will drop as the reaction proceeds, and the reaction may become unacceptably slow before reaching the desired amount of reaction. In case of exothermic reactions, the temperature of adiabatic reaction may be higher than the

\footnotetext{
* Corresponding author. Tel.: +39 250314253; fax: +39 250314300

E-mail address: claudia.bianchi@unimi.it (C.L. Bianchi).
}

one which economically reasonable reactor materials can withstand, or high temperatures may lead to unfavourable equilibriums or production of unwanted by-products.

This allows us to add heat to an endothermic reaction or to remove it from an exothermic reaction while still having separate heat exchangers and reactors, or separate heat exchange and reaction sections within the same reactor. Finally, we could have continuous heat addition or removal through the wall of the fixed bed reactor. This will require a reactor with a fairly small diameter so that heat transfer in or out of it is fast enough to avoid unacceptable temperature gradients in the radial direction.

Another problem is the formation of localized hot spots inside the catalytic bed. If the catalyst is exposed to too high a temperature, undesired products will be formed, which may damage the structural integrity of the catalyst (for example, carbon in Fischer-Tropsch synthesis).

The Fischer-Tropsch synthesis (FTS) reaction for the production of ultra-clean chemicals and fuels (gasoline, diesel and hydrocarbon waxes) from syngas $\left(\mathrm{CO}\right.$ and $\left.\mathrm{H}_{2}\right)$ is mainly carried out in the gas phase. Two types of reactors were industrially applied [1]: a tubular fixed bed (TFB) reactor was used for the production of high molecular weight hydrocarbons (waxes) and diesel, and a circulated fluidized bed $(\mathrm{CFB})$ reactor for the production of 
gasoline. Both of the reactors had to face major problems. The high temperature operation of TFB required a method of in situ heat removal in order to suppress the production of methane and light hydrocarbons, as well as to avoid catalyst deactivation. Furthermore, the low conversion in the CFB (whereby low temperature is necessary for the production of gasoline) required costly recycling. Slurry bubble reactors $(\mathrm{SBC})$ were industrially applied later for the FTS to overcome the limitations of both TFB and CFB.

One possible solution is to use diluents, i.e., inactive ceramic bodies that prevent hot spots in a catalytic bed, by uniformly reducing its activity. These bodies must be tailored to mix intimately with the catalyst without affecting the fluid flow through the catalyst bed. The main problem is to choose the best material to be used as diluent: obviously, it must be as inert as possible and it should not act as a catalyst for the reaction.

Due to their high activity and long life, cobalt-based and iron-based Fischer-Tropsch catalysts are currently the catalysts of choice for the conversion of syngas into liquid fuels. The exothermic nature of the Fischer-Tropsch reaction $\left(\Delta H=-146 \mathrm{~kJ} / \mathrm{mol} C_{\text {reacted }}\right)$ combined with the high activity of these metals makes the removal of heat from the reactor critically important.

In the present paper, the use of several materials used as diluent is fully discussed. In particular, it was verified the possible synergetic effects between the active catalytic metal ( $\mathrm{Fe}$ or $\mathrm{Co}$ ) and the chosen diluent.

\section{Experimental}

\subsection{Preparation of catalysts}

They were prepared according to the traditional impregnation method, using a commercially available $\mathrm{SiO}_{2}$ support (BET surface area: $520 \mathrm{~m}^{2} \mathrm{~g}^{-1}$, pore volume: $1.22 \mathrm{ml} \mathrm{g}^{-1}$ and pore diameter: $8.7 \mathrm{~nm}$ ) and cobalt nitrate or iron (II) nitrate (all Fluka products) by calcinations of the nitrate precursor at $450{ }^{\circ} \mathrm{C}$ for $4 \mathrm{~h}$, followed by $\mathrm{H}_{2}$ reduction at $400{ }^{\circ} \mathrm{C}$ for $6 \mathrm{~h}$. The reduced catalysts were passivated in a stream of $1 \% \mathrm{O}_{2} / \mathrm{He}$ at room temperature before being transferred from the reduction cell. The weight ratio of cobalt or iron to silica was 0.10 .

\subsection{Diluent}

All commercial materials were used as diluent (Fluka): $\mathrm{SiO}_{2}$ (the same material used as catalyst support), $\mathrm{SiC}$ (BET surface area: $0.8 \mathrm{~m}^{2} / \mathrm{g}$ ) and $\alpha-\mathrm{Al}_{2} \mathrm{O}_{3}\left(4 \mathrm{~m}^{2} / \mathrm{g}\right.$ ).

\section{3. $T G A$}

The TGA experiments on the presented supports were performed with a Thermogravimetric Analyzer TGA XP$10^{\mathrm{TM}}$ (THASS $^{\mathrm{TM}}$ ). An isothermal step was maintained at $220{ }^{\circ} \mathrm{C}$ for about $4 \mathrm{~h}$ (the temperature was raised from 20 to $220^{\circ} \mathrm{C}$, before the isothermal step, with a velocity of
$10{ }^{\circ} \mathrm{C} / \mathrm{min}$ ). The dry runs were performed with a nitrogen flux introduced directly in the sample cell while in the wetruns the same nitrogen flux was bubbled into a flask containing distilled water, before incoming into the sample cell.

\subsection{Catalytic test}

FT synthesis was performed into a fixed bed reactor, using $1 \mathrm{~g}$ of fresh catalyst mixed with $1 \mathrm{~g}$ of diluting material. The reduced catalyst was initially activated in situ in $30 \mathrm{ml} / \mathrm{min}$ flow of $\mathrm{H}_{2}$ at $350{ }^{\circ} \mathrm{C}, 0.8 \mathrm{MPa}$ for $4 \mathrm{~h}$. Then, it was tested in $36 \mathrm{ml} / \mathrm{min}$ flow of syngas with $\mathrm{H}_{2} / \mathrm{CO}$ ratios of $2 / 1$ at $2.0 \mathrm{MPa}$ and $220^{\circ} \mathrm{C}$. Analyses of the gas-phase products $\left(\mathrm{C}_{1}-\mathrm{C}_{7}\right)$ were performed with an on-line microgaschromatograph (Agilent); measurements were carried out every 5 min. during the reaction. Liquid products were collected in a trap at room temperature and analyzed by a gas chromatography (Thermo) equipped with a Poparak-Q column (being able to separate $\mathrm{C}_{8}-\mathrm{C}_{32}$ hydrocarbons fraction) after the reaction for $60 \mathrm{~h} \mathrm{[2].}$

\section{Results and discussion}

In the literature, no systematic work has been reported on the influence of such materials on the overall reaction and many of them have been used to dilute the same kind of catalysts without any particular reason (some examples are reported in Table 1).

Table 2 lists the results of conversion and selectivity obtained both on Co and Fe-based catalysts; the activity of pure $\mathrm{SiO}_{2}$ is also reported to confirm that the support is really inert towards the reaction. Each run was repeated ten times, at least, using always a fresh batch of catalyst.

It is possible to observe that for each chosen catalyst it is necessary to couple its own diluent. In fact, the presence of a diluent greatly modifies the $\mathrm{CO}$ conversion, but the selectivity also dramatically changes.

The most important difference between these three inert materials is their behaviour towards water absorption. Water is directly and largely produced during the FT synthesis

Table 1

Literature data

\begin{tabular}{|c|c|c|}
\hline Catalyst & Diluent & Reference \\
\hline $12.7 \% \mathrm{Co} / \mathrm{SiO}_{2}$ & $\mathrm{SiO}_{2}$ & {$[3]$} \\
\hline $0.5 \% \mathrm{Re}-12 \% \mathrm{Co} / \gamma-\mathrm{Al}_{2} \mathrm{O}_{3}$ & $\mathrm{SiC}$ & [4] \\
\hline \multicolumn{3}{|l|}{$0.5 \% \mathrm{Re}-12 \% \mathrm{Co} / \mathrm{SiO}_{2}$} \\
\hline \multicolumn{3}{|l|}{$0.5 \% \mathrm{Re}-12 \% \mathrm{Co} / \mathrm{TiO}_{2}$} \\
\hline $21.9 \% \mathrm{Co} / \mathrm{SiO}_{2}$ & $\mathrm{SiO}_{2}$ & {$[5]$} \\
\hline $12.5 \% \mathrm{Co} / \mathrm{SiO}_{2}$ & Glass beads & [6] \\
\hline $\mathrm{Zr}-15 \% \mathrm{Co} / \mathrm{SiO}_{2}$ & $\mathrm{SiC}$ & [7] \\
\hline $14.2 \% \mathrm{Co} / \mathrm{Al}_{2} \mathrm{O}_{3}$ & $\alpha-\mathrm{Al}_{2} \mathrm{O}_{3}$ & [8] \\
\hline $\mathrm{Fe}-\mathrm{Zn}-\mathrm{Cu}-\mathrm{K} / \mathrm{SiO}_{2}$ & $\mathrm{SiO}_{2}$ & {$[5]$} \\
\hline \multicolumn{3}{|l|}{$\mathrm{Fe}-\mathrm{Zn}-\mathrm{Cu}-\mathrm{Ru} / \mathrm{SiO}_{2}$} \\
\hline $\mathrm{Pt}-\mathrm{Fe} / \mathrm{SiO}_{2}$ & Quartz chips & [9] \\
\hline $\mathrm{Fe} / \mathrm{SiO}_{2}$ & Silica sand & {$[10]$} \\
\hline $\mathrm{Fe}-\mathrm{Al}-\mathrm{Cu}-\mathrm{K}$ & Fused silica & [11] \\
\hline
\end{tabular}


Table 2

Fischer-Tropsch synthesis performed at $220^{\circ} \mathrm{C}, 36 \mathrm{ml} / \mathrm{min}$ flow of syngas with $\mathrm{H}_{2} / \mathrm{CO}$ ratios of $2 / 1$ and $2.0 \mathrm{MPa}$

\begin{tabular}{lllcccc}
\hline Catalyst & Diluent & $\begin{array}{l}\text { Conversion } \\
\mathrm{CO}(\%)\end{array}$ & \multicolumn{5}{c}{ Selectivity (\%) } \\
\cline { 5 - 7 } & $1 / 1$ & \multicolumn{1}{c}{$\mathrm{CO}_{2}$} & $\mathrm{CH}_{4}$ & $\mathrm{C}_{2}-\mathrm{C}_{7}$ & $>\mathrm{C}_{8}$ \\
\hline Pure $\mathrm{SiO}_{2}$ & - & 0 & 0 & 0 & 0 & 0 \\
$\mathrm{Co} / \mathrm{SiO}_{2}$ & - & 37.8 & 8.9 & 8.9 & 13.3 & 68.9 \\
& $\mathrm{SiO}_{2}$ & 66.4 & 7.2 & 4.8 & 17.7 & 70.3 \\
& $\alpha-\mathrm{Al}_{2} \mathrm{O}_{3}$ & 36.7 & 12.2 & 14.5 & 33.3 & 40.0 \\
& $\mathrm{SiC}$ & 49.2 & 8.6 & 8.6 & 2.5 & 80.3 \\
$\mathrm{Fe} / \mathrm{SiO}_{2}$ & - & 9.3 & 60.2 & 3.8 & 34.1 & 1.9 \\
& $\mathrm{SiO}_{2}$ & 13.4 & 49.6 & 4.0 & 44.6 & - \\
& $\alpha-\mathrm{Al}_{2} \mathrm{O}_{3}$ & 18.7 & 24.7 & 14.0 & 55.1 & - \\
& $\mathrm{SiC}^{n}$ & 11.1 & 45.4 & 2.1 & 27.7 & 24.8 \\
\hline
\end{tabular}

$\mathrm{CO}+(1+x) \mathrm{H}_{2} \Longleftrightarrow \mathrm{CH}_{2 x}+\mathrm{H}_{2} \mathrm{O}$

and it may cause the catalyst surface oxidation.

It is generally accepted that the oxidation rate for ironand cobalt-based catalysts increases with the water partial pressure [12]. It is also recognized that the oxidation rate is higher for Fe-based catalysts, compared to cobalt-based ones [12]. This means that the in situ removal of the FT reaction water will cause a decrease in the oxidation rate - the decrease being more pronounced, the higher is the amount of water removed - and an increase in the catalyst activity.

In addition, as for iron-based catalysts, water has an inhibiting effect on the rate of reaction; therefore, for these catalysts, the removal of the reaction water will result in higher per-pass conversions, due to a more favourable kinetic environment [12].

On the other hand, for cobalt-based catalysts, the situation is more complex. On alumina supported catalysts, Hilmen et al. [13] and Jacobs et al. [14] found a faster deactivation of the catalyst when the water was added to the feed mixture, and the latter also observed a different deactivation behaviour depending on the effective metal loading and particle size: for low loading (and cobalt clusters between 5 and $6 \mathrm{~nm}$ ) the oxidation is likely to include the reaction with the support, resulting in the formation of cobalt-aluminate species (e.g. $\mathrm{Co}_{2} \mathrm{AlO}_{4}$ ). On the contrary, for high loading (and bigger Co clusters), the oxidation by $\mathrm{H}_{2} \mathrm{O}$ may cause the formation of $\mathrm{CoO}$, which can be once more reduced by the feed gas $\left(\mathrm{H}_{2} / \mathrm{CO}\right)$ but only in the absence of water. Moreover, these oxidation-reduction cycles lead to a sintering of clusters.

For silica supported cobalt catalysts, Krishnamoorthy et al. [3] reported a positive deviation on the FT synthesis rate, by adding water.

To verify the different behaviour of the diluents towards water, some TGA experiments were performed at the same temperature $\left(220^{\circ} \mathrm{C}\right)$ used during our FT synthesis tests (Figs. 1 and 2).

It can be observed that $\mathrm{SiO}_{2}$ absorbs water and keeps it throughout the test, as demonstrated by the flat slope of the wet line. On the contrary, $\alpha-\mathrm{Al}_{2} \mathrm{O}_{3}$ (and $\mathrm{SiC}-$ not shown for reason of space) does not absorb water and, in fact, the two TGA lines have a very similar slope.

Therefore, all the diluents increase the $\mathrm{CO}$ conversion improving the loss of heat, but it is necessary to remember that silica has also the property to maintain a high water partial pressure near the catalyst and this may cause a strong modification of the selectivity towards the products, depending on the kind of used active metal.

\section{Conclusions}

The heat removal in fixed bed reactors is an important target especially for highly exothermic reactions and can

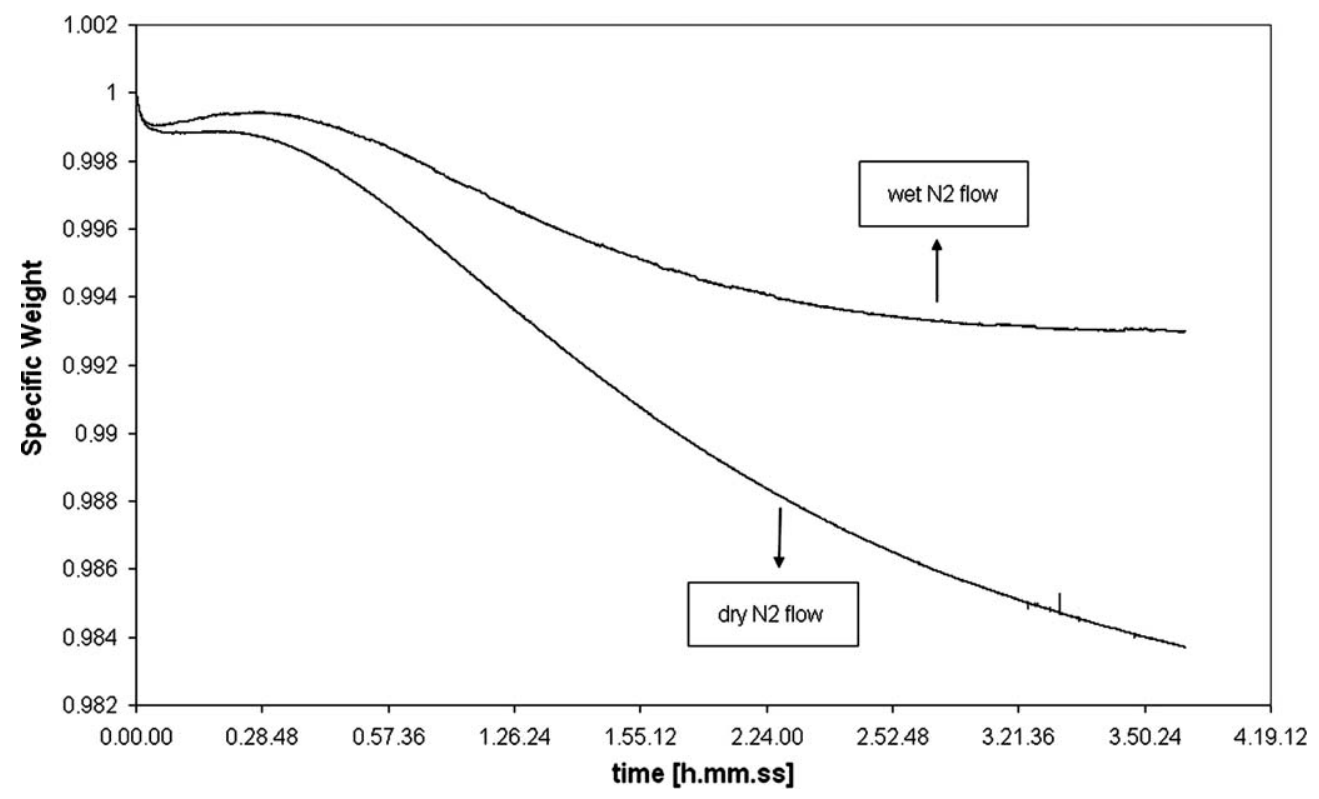

Fig. 1. TGA performed on $\mathrm{SiO}_{2}$ at $220^{\circ} \mathrm{C}, 3 \mathrm{~h}$ (dry $\mathrm{N}_{2}$ flow: upper line). 


\section{ARTICLE IN PRESS}

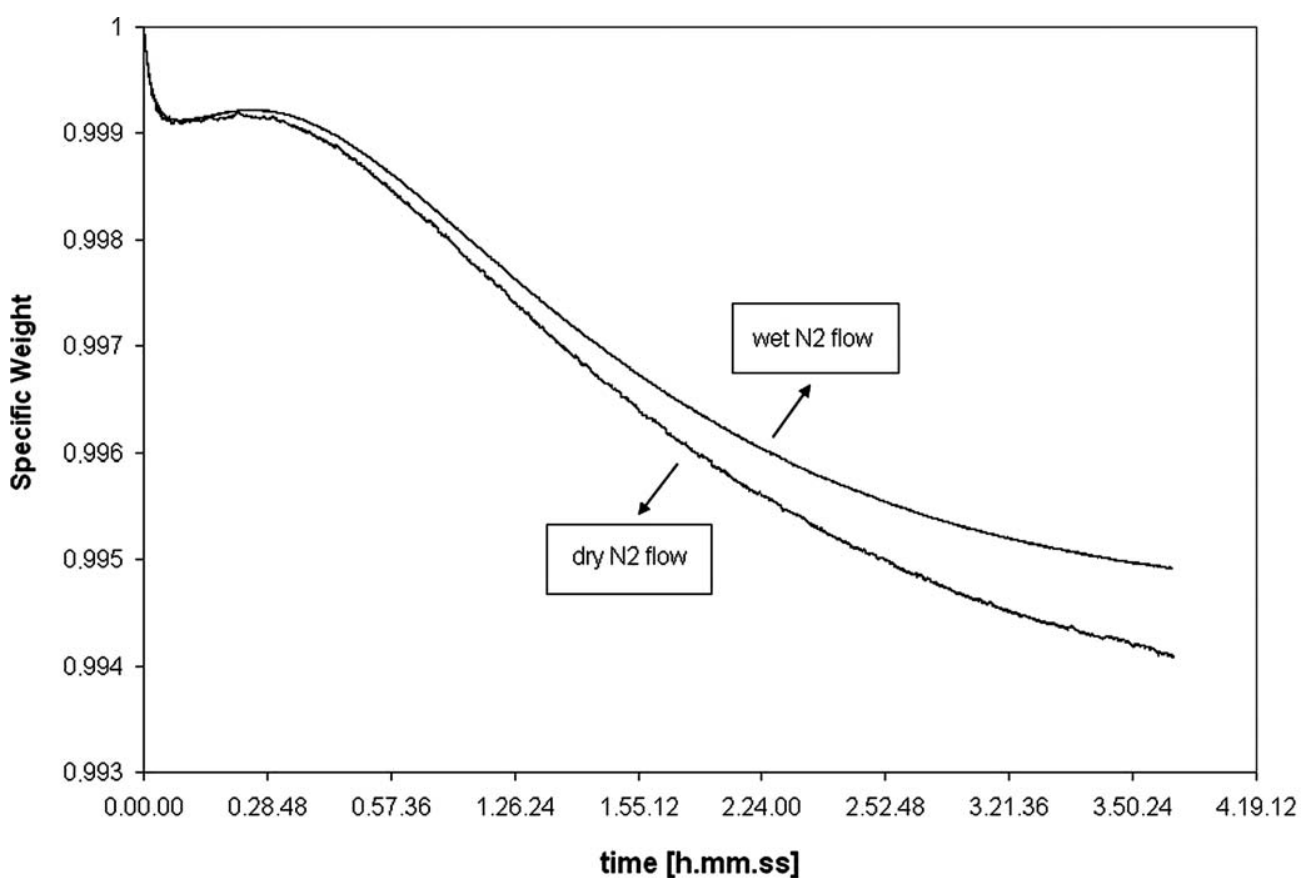

Fig. 2. TGA performed on $\alpha-\mathrm{Al}_{2} \mathrm{O}_{3}$ at $220{ }^{\circ} \mathrm{C}, 3 \mathrm{~h}$ (wet $\mathrm{N}_{2}$ flow: upper line).

be partially solved adding a diluent material mixed with the solid catalyst.

In the case of Fischer-Tropsch synthesis the choice of the right diluent is and important aspect and it is necessary to evaluate not only the diluent inactivity towards the reaction, but also its possible synergetic effects towards the existing catalyst. In fact, improvements of the catalyst performances, increasing the $\mathrm{CO}$ conversion, but also a modification of the hydrocarbons selectivities were observed. This behaviour finds a first explanation in the different water partial pressure maintained by the material in the closeness of the catalyst active metal.

\section{Acknowledgements}

This work was financially supported by FIRB Project (RBAU01HMMF) and Italian CNR subcontract.

\section{References}

[1] R.L. Espinoza, A.P. Steynberg, B. Jager, A. Vosloo, Appl. Catal. A 186 (1999) 13.
[2] C.L. Bianchi, V. Ragaini, Catal. Lett. 95 (2004) 61.

[3] S. Krishnamoorthy, M. Tu, M.P. Ojeda, D. Pinna, E. Iglesia, J. Catal. 211 (2002) 422.

[4] S. Storsæter, Ø. Borg, E.A. Blekkan, B. Tøtdal, A. Holmen, Catal. Today 100 (2005) 343.

[5] S. Li, S. Krishnamoorthy, A. Li, G.D. Meitzner, E. Iglesia, J. Catal. 206 (2002) 202.

[6] G. Jacobs, K. Chaudhari, D. Sparks, Y. Zhang, B. Shi, R. Spicer, T.K. Das, J. Li, B.H. Davis, Fuel 82 (2003) 1251.

[7] H. Xiong, Y. Zhang, K. Liew, J. Li, J. Mol. Catal. A 231 (2005) 145.

[8] D. Pinna, E. Tronconi, L. Lietti, R. Zennaro, P. Forzatti, J. Catal. 214 (2003) 251.

[9] J. Xu, C.H. Bartolomew, J. Sedweeks, D.L. Eggett, Topics Catal. 26 (2003) 55.

[10] B.-T. Teng, J. Chang, J. Yuang, G. Wang, C.H. Zhang, Y.-Y. Xu, H.W. Xiang, Y.-W. Li, Fuel 84 (2005) 917.

[11] T. Riedel, H. Schulz, G. Schaub, K.-W. Jun, J.-S. Hwang, K.-W. Lee, Topics Catal. 26 (2003) 41.

[12] R.L. Espinoza, E. du Toit, J. Santamaria, M. Menendez, J. Coronas, S. Irusta, Studies Surf. Sci. Catal. 130 (2000) 389.

[13] A.M. Hilmen, D. Schanke, K.F. Haussen, A. Holmen, Appl. Catal. A 186 (1999) 169.

[14] G. Jacobs, P.M. Patterson, T.K. Das, M. Luo, B.H. Davis, Appl. Catal. A 270 (2004) 65. 